\title{
Front Matter: Volume 11845
}

, "Front Matter: Volume 11845," Proc. SPIE 11845, Saratov Fall Meeting 2020: Optical and Nanotechnologies for Biology and Medicine, 1184501 (4 May 2021); doi: $10.1117 / 12.2599482$

SPIE. Event: Saratov Fall Meeting 2020, 2020, Saratov, Russian Federation 


\title{
PROG RESS IN BIOMEDICAL OPTICS AND IMAG ING \\ Vol. 22 No. 56
}

\section{Sa ratov Fall Meeting 2020 \\ Optical and Nanotec hnologies for Biology and Medic ine}

\author{
Valery V. Tuc hin \\ Eina A. Genina \\ Editors
}

\section{September - 2 October 2020 \\ Saratov, Russian Federation}

\section{Sponsored by}

Russian Foundation for Ba sic Research (Russian Federation) - Ministry of Science and Higher Educ ation of the Russian Federation - Sa ratov State University (Russian Federation) - Russian Academy of Sc iences (Russian Federation) • OSA - The Optic al Soc iety - IEEE - Institute of Electric al a nd Electronic s Engineers • Russian Tec hnology Platform "The Medic ine of the Future" (Russian Federation) • Russian Technology Platform "Photonics" (Russian Federation) • European Technology Platform "Photonic s21" • Sa mara University (Russian Federation) • INJ ECTRME LLC, Saratov (Russian Federation) • UC SPE Na nostructured Glass Technology, Saratov (Russian Federation) - Becker \& Hickl GmbH (Gemany) • artphotonic s GmbH (Gemany) - Research Center of Biotechnology RAS (Russian Federation) - Technolnfo Ltd. (Russian Federation) - MR Solutions (United Kingdom) • PicoQuant (Germany) • InterLabService Ltd. (Russian Federation) • BioLine Group (Russian Federation) - Aspect Imaging Ltd. (Israel) • J oumal of Innovative Optical Health Sciences (China) • J oumal PHOTONICS RUSSIA (Russian Federation)

\section{Cooperating Organizations}

Russian Soc iety for Photobiology (Russian Federation) • Saratov Science Center of the RAS (Russian Federation) - Biophotonic s.World: The World wide Consortium Biophotonic s4Life - EPIC - European Photonic s Ind ustry Consortium

Technic al Cosponsor and Publisher SPIE

Volume 11845 
The papers in this volume were part of the technical conference cited on the cover and title page. Papers were selected and subject to review by the editors and conference program committee. Some conference presentations may not be available for publication. Additional papers and presentation recordings may be available online in the SPIE Digital Library at SPIEDigitalLibrary.org.

The papers reflect the work and thoughts of the authors and are published herein as submitted. The publisher is not responsible for the validity of the information or for any outcomes resulting from reliance thereon.

Please use the following format to cite material from these proceedings:

Author(s), "Title of Paper," in Saratov Fall Meeting 2020: Optical and Nanotechnologies for Biology and Medicine, edited by Valery V. Tuchin, Elina A. Genina, Proc. of SPIE 11845, Seven-digit Article CID Number (DD/MM/YYYY); (DOI URL).

ISSN: 1605-7422

ISSN: 2410-9045 (electronic)

ISBN: 9781510645288

ISBN: 9781510645295 (electronic)

Published by

SPIE

P.O. Box 10, Bellingham, Washington 98227-0010 USA

Telephone +1 3606763290 (Pacific Time)

SPIE.org

Copyright (C) 2021 Society of Photo-Optical Instrumentation Engineers (SPIE).

Copying of material in this book for internal or personal use, or for the internal or personal use of specific clients, beyond the fair use provisions granted by the U.S. Copyright Law is authorized by SPIE subject to payment of fees. To obtain permission to use and share articles in this volume, visit Copyright Clearance Center at copyright.com. Other copying for republication, resale, advertising or promotion, or any form of systematic or multiple reproduction of any material in this book is prohibited except with permission in writing from the publisher.

Printed in the United States of America by Curran Associates, Inc., under license from SPIE.

Publication of record for individual papers is online in the SPIE Digital Library.

\section{SPIE. DIGITAL}

Paper Numbering: A unique citation identifier (CID) number is assigned to each article in the Proceedings of SPIE at the time of publication. Utilization of CIDs allows articles to be fully citable as soon as they are published online, and connects the same identifier to all online and print versions of the publication. SPIE uses a seven-digit CID article numbering system structured as follows:

- The first five digits correspond to the SPIE volume number.

- The last two digits indicate publication order within the volume using a Base 36 numbering system employing both numerals and letters. These two-number sets start with 00, 01, 02, 03, 04, 05, 06, 07, 08, 09, 0A, OB ... 0Z, followed by 10-1Z, 20-2Z, etc. The CID Number appears on each page of the manuscript. 


\section{Contents}

INVITED PAPERS

1184502 Autofluorescence detection of lower tract gastrointestinal neoplasia (Invited Paper) [11845-25]

1184503 Relaxation and osmotic-induced slow strain mapping in biological tissues by optical coherence elastography (Invited Paper) [11845-38]

1184504 Cross-checking the effect of roughness on the stability of photoacoustic conversion from gold nanorods (Invited Paper) [11845-36]

1184505 Multiparameter optical methods and instruments for the diagnostics of human body mic roc irc ulatory-tissue systems (Invited Paper) [11845-48]

1184506 Metabolism of stem cell grown on heterogeneous tissue-engineered scaffolds (Invited Paper) [11845-22]

1184507 Ultrasonic modes to improve the optical clearing of the skin ex vivo (Invited Papen) [11845-23]

1184508 The assessment of tumor vasc ularization degree for predic ting the effectiveness of plasmonic photothermal and photodynamic therapy (Invited Paper) [11845-28]

\section{OPIICALTECHNOLOGIES IN MICROBIOLOGY, BIOLOGY, AND MEDICINE}

1184509 Application of digital speckle pattems comelation for blood clotting time evaluation [11845-5]

11845 OA Study of properties of virtual laser GB-speckles, generated on nucleotide sequences of the SARS-CoV-2 gene " $N$ " [11845-9]

11845 OB Differentiation of Highly Pathogenic Avian Influenza Virus (HPAIV) A strains using of GBspeckles, generated for the nucleotide sequences of the neuraminidase gene [11845-10]

11845 OC The GB-speckles generated forthe gene pgp4 as the promising model towards to differentiation of some Chlamydia spp. [11845-11]

11845 OD Comparison of structural and statistical charactenistics of interfering GB speckles, generated for the nuc leotide sequences of the gene GPCR of lumpy skin disease vinus and sheep-pox virus [11845-13]

$118450 \mathrm{E} \quad$ LASCA monitoring of dose-dependent dynamics of tumor growth under the influence of Chlamydia psittaci AMK-16 specific omithosis antigen [11845-16] 
11845 OF Red-colored water in the supralittoral zone of the Alaid Volcano: long-term spectroscopic observations [11845-43]

11845 OG Optical properties of humic substances in the coastal waters of the White Sea based on the results of 2020 expeditions [11845-60]

$11845 \mathrm{OH} \quad$ Fuorescence of chlorosomal bacteriochlorophylls extracted by organic solvents applied for pigment quantification in natural water samples [11845-61]

11845 ol Luminescent and physiological indices of potato after the treatment of tubers with growth regulators [11845-57]

11845 0] Excitation-dependent emission spectra of fungal fluorophores in tems of their similarity to fluorescence of dissolved organic matter [11845-59]

11845 OK NADH growth rate evaluation in different rat brain regions by fluorescence spectrosc opy [11845-44]

$11845 \mathrm{OL}$ Measurements of mitochondrial NADH pool and NADH production rate in acute brain slices and primary cell cultures using live cell imaging [11845-45]

11845 OM Impact of ex vivo skin dehydration on collimated transmittance spectra kinetics [11845-26]

11845 ON A method for evaluation of absolute and relative blood flow velocities in soft biological tissues using optical coherence tomography [11845-30]

1184500 Evaluation of geometric characteristics and intemal structure of atherosclerotic plaques on the walls of the blood vessels and their phantoms using intravasc ular optical coherence tomography [11845-31]

11845 OP Tissue-like phantoms mimic king blood vessel for intravasc ular optical coherence tomography [11845-33]

11845 0Q Quality control of tablets "Papazol" by spectrophotometry using chemometrics [11845-39]

11845 OR Spectral analysis of human exhaled breath for early diagnosis of diseases using different machine leaming methods [11845-54]

11845 OS Expenimental setup and method for human breath analysis for the primary diagnosis of diseases [11845-63]

11845 OT Application of terahertz pulsed spectroscopy for analysis of ex vivo biological tissue freezing [11845-58]

11845 OU Simulation of the effect of purulent content of the maxillary sinuses on the tansillumination signal [11845-62]

11845 OV Determination of the binary diffusion coeffic ient of an iodine-glycerol preparation (lugol) in the dentin of a human tooth [11845-65] 
$11845 \mathrm{OW}$ Improved optical access of laser radiation to the brain using optical clearing and transparent cranial implants: review [11845-71]

11845 0X Some steps in the development of an immunochromatographic test to quantify cortisol in human salivary fluid [11845-6]

\section{LASER APPUCATIONS IN THERAPY AND SURGERY}

11845 oY Combined lasertherapy for the treatment of psoriasis [11845-21]

$118450 Z$ Optical properties of model cholangiocarcinoma tissues in the spectral range of 350-2250 nm in laser photothemolysis treatment [11845-29]

1184510 Optics and themodynamics of titanium-containing optothemal fiber converterand vein wall during endovasal lasercoagulation [11845-34]

\section{MICRO- AND NANOBIOTECHNOLOGY}

1184511 Petal-like gap-enhanced Raman tags with a controllable structure [11845-8]

1184512 The potential of gold nanopartic les for coronavinus diagnosis and prophylaxis [11845-40]

1184513 Core type as a factor of gap-enhanced Raman tags SERS response [11845-27]

1184514 Luminescent carbon nanostructures as a 'green' nanosensor for detection of heavy metal ions [11845-41]

1184515 Glauconite-based antibactenial composites with copper nanopartic les [11845-37]

1184516 Is it possible to reuse growth cetyltrimethylammonium bromide solution of gold nanorods? [11845-47]

1184517 2-mercaptoethanol and dihydrolipoic acid biligand-coated alloyed quantum dots [11845-53]

1184518 Synthesis and size-exc lusion fractionation of luminescent carbon nanostructures [11845-19]

1184519 A theoretical model for the delivery of magnetic nanoparticles through a blood vessel under the influence of a magnetic field [11845-50]

$118451 \mathrm{~A} \quad$ Non-coherent video-reflectometry of growing pores in plastic ized polymers during superc ritical fluidic foaming [11845-17]

11845 1B Image processing procedures for quantification of bubble gem growth/collapse in synthesized highly-porous polymer matrices [11845-18] 
$118451 \mathrm{C}$ Influence of induction chemical-themal treatment in a gaseous medium on the formation of a wear-resistant gradient nitride layer on tool steel [11845-42]

11845 1D Researching of the structural and morphological characteristics of coatings based on metalcontaining calcium phosphates [11845-49]

$11845 \mathrm{IE} \quad$ Influence of induction treatment on the steel-titanium layered structure to obtain a highly hard working titanium-oxide surface [11845-66]

11845 IF Numerical simulation of induction vac uum deposition of titanium on steel plates [11845-67]

$118451 \mathrm{G}$ Optical magnet for nanopartic les manipulations based on optical vac uum cleaner concept [11845-68]

$11845 \mathrm{1H} \quad$ Influence of the geometry and c ument of the inductor on the process of chemical heat treatment of titanium in a container with a carbon-containing medium [11845-69]

$1184511 \quad$ Evaluation of low-coherence interference fringe parameters by the adaptive Wiener filtering method [11845-52]

11845 1] Influence of a low-intensity electromagnetic field on the process of self-assembly of the core histones H3.2 and H4 [11845-20]

$118451 \mathrm{~K} \quad$ Hollow core mic rostructured optical fibers as support for synthesis of molec ularty imprinted polymers [11845-24] 


\title{
Conference Organizers
}

\author{
Saratov State University (Russian Federation) \\ Research-Educational Institute of Optics and Biophotonics of Saratov State \\ University (Russian Federation) \\ International Research-Educational Center of Optics and Biophotonics of Saratov \\ State University (Russian Federation) \\ Institute of Biochemistry \& Physiology of Plants \& Microorganisms of the RAS \\ (Russian Federation) \\ Institute of Precision Mechanics and Control of the RAS (Russian Federation) \\ Saratov State Medical University named after V.I. Razumovsky \\ (Russian Federation) \\ Volga Region Center of New Information Technologies of Saratov State University \\ (Russian Federation) \\ Tomsk State University (Russian Federation) \\ ITMO University (Russian Federation) \\ Bauman Moscow State Technical University (Russian Federation) \\ Institute of Solid-State Physics of the RAS (Russian Federation) \\ Prokhorov Institute of General Physics of the RAS (Russian Federation) \\ Bach Institute of Biochemistry, Research Center of Biotechnology of the RAS \\ (Russian Federation) \\ Sechenov First Moscow State Medical University (Russian Federation) \\ Institute of Ultra-High Frequency Semiconductor Electronics of the RAS \\ (Russian Federation) \\ Biomedical Photonics Committee of Chinese Optical Society (China) \\ SPIE Student Chapters of: \\ Saratov State University (Russian Federation), \\ Bauman Moscow State Technical University (Russian Federation), \\ Institute of Solid-State Physics of the RAS (Russian Federation), and \\ Samara University (Russian Federation) \\ OSA Student Chapters of: \\ Saratov State University (Russian Federation) and \\ Bauman Moscow State Technical University (Russian Federation)
}


Proc. of SPIE Vol. 11845 1184501-8

Downloaded From: https://www.spiedigitallibrary.org/conference-proceedings-of-spie on 26 Apr 2023
Terms of Use: https://www.spiedigitallibrary.org/terms-of-use 